\title{
Effect of Lactobacillus plantarum as adjunct starter on the flavour and texture of a semi-hard cheese made from pasteurised cows' milk
}

\author{
MJ Gomez, P Gaya, M Nuñez, M Medina* \\ Departamento de Tecnología de Alimentos, CIT-INIA, \\ Carretera de La Coruña km 7, Madrid 28040, Spain
}

(Received 6 March 1996; accepted 29 April 1996)

\begin{abstract}
Summary - The effect of Lactobacillus plantarum ESI 144 as starter adjunct on the chemical, textural and sensory characteristics of a semi-hard cows' milk cheese was investigated. Lactobacilli lowered cheese $\mathrm{pH}$ during early manufacture, reducing casein degradation and formation of soluble $\mathrm{N}$. Higher apparent elastic modulus, breaking force and hardness values were recorded for cheeses with added lactobacilli, as a consequence of the less pronounced proteolysis. In cheese made from milk to which Bacillus subtilis neutral proteinase was added to induce bitter flavour formation, the use of $L$ plantarum as adjunct starter resulted in lower levels of hydrophobic peptides from day 1 and lower bitterness scores throughout ripening.
\end{abstract}

\section{L plantarum / cheese / proteolysis / texture / bitterness}

Résumé - L'influence de Lactobacillus plantarum comme levain additionnel sur la saveur et la texture d'un fromage à pâte pressée fabriqué à partir de lait pasteurisé de vache. L'influence de l'utilisation de Lactobacillus plantarum ESI 144 comme levain additionnel sur les caractéristiques chimiques, texturales et sensorielles d'un fromage à pâte pressée fabriqué à partir de lait pasteurisé de vache, a été étudiée. Les lactobacilles abaissaient le $\mathrm{pH}$ du fromage pendant les premières heures de fabrication, entraînant une diminution de la dégradation des caséines et de la formation de l'azote soluble. Des valeurs plus élevées du module d'élasticité, de la force au seuil de rupture et de la dureté (travail à une déformation de $75 \%$ ) ont été trouvées pour les fromages fabriqués avec l'addition de lactobacilles, comme conséquence d'une protéolyse moins intense. Dans des fromages fabriqués à partir de lait additionné de la protéinase neutre de Bacillus subtilis pour favoriser l'apparition de l'amertume, l'utilisation de L plantarum comme levain additionnel a conduit à une diminution des peptides hydrophobes visible dès le premier jour d'affinage et de l'amertume pendant tout l'affinage.

\section{L plantarum / fromage / protéolyse / texture / amertume}

${ }^{\star}$ Correspondence and reprints. 


\section{INTRODUCTION}

Development of bitterness in cheese has been attributed to the formation and accumulation of bitter peptides from the hydrophobic fragments of caseins by the action of rennet, starter culture or other micro-organisms (Visser, 1977). The addition of lactobacilli as adjuncts to the starter has been tried as a method to reduce the accumulation of bitter peptides in cheese (Bartels et al, 1987a; Lemieux et al, 1989).

Heat- and freeze-shocked cultures of Lactobacillus helveticus ATCC 10797 and CNRZ 32 decreased bitterness and increased proteolysis and flavour intensity in Gouda cheese (Bartels et al, 1987a, b). Ardö and Pettersson (1988) reported synergistic effects of the addition of free neutrase and heat-treated $L$ helveticus CNRZ 303 cultures in the acceleration of Swedish hard cheese ripening. Enhancement of peptidolysis by heat-treated cultures of $L$ helveticus CNRZ 303 was observed during early maturation in low-fat cheese, with increased cheese flavour intensity and reduced bitterness (Ardö et al, 1989).

The use of mesophilic lactobacilli as adjuncts to the starter has also been investigated. The addition of whole cells of $L$ casei subsp casei CNRZ 62 in Cheddar cheese manufacture produced only a slight increase in proteolysis (El Soda et al, 1981). L casei subsp casei isolates from Cheddar cheese have been suggested as potential strains to accelerate ripening because of their wide ranges of peptidase activity (Arora and Lee, 1990). Body and texture of Cheddar cheese with added $L$ casei subsp casei strains CV1A and MIL2B were unaffected, whereas increases in peptide degradation and development of flavour intensity were observed by Broome et al (1990). Live cells and cell homogenates from $L$ casei subsp casei L2A led to good quality Cheddar cheese with increased flavour intensity (Trépanier et al, 1991a, b).
Crude enzyme extracts of $L$ casei subsp casei LLG with active aminopeptidase and proline-specific peptidases hydrolysed two hydrophobic peptides released from $\alpha_{s 1}$ and $\beta$-casein in bitter enzyme-modified cheese (Park et al, 1995). L casei subsp casei L2A accelerated maturation without imparting bitterness to Cheddar cheese, but $L$ plantarum 99 and $L$ brevis 35.4 produced off-flavours in Cheddar cheese when added as adjuncts to accelerate cheese ripening (Lemieux et al, 1989).

L plantarum ESI 144 , a strain isolated from raw milk cheese, exhibited potential debittering activity in model cheeses (Gomez et al, 1996). The purpose of the present work was to evaluate its effect on the chemical, textural and sensory characteristics of a semi-hard cows' milk cheese, with special attention to the debittering activity in cheese enriched in bitter peptides by addition of neutrase, a commercial preparation of Bacillus subtilis neutral proteinase (BSNP).

\section{MATERIALS AND METHODS}

\section{Cheese manufacture}

Cheeses were elaborated in duplicate experiments. In each experiment, pasteurised (15 s at $75^{\circ} \mathrm{C}$ ) cows' milk was divided into four 60 -L vats. Milk at $30^{\circ} \mathrm{C}$ was inoculated (1\%) with a coagulated culture in milk of the mesophilic starter CH-NO1 (Chr Hansen-Lacta SL, Madrid, Spain). Vats 2 and 4 were inoculated $(1 \%)$ with a culture of $L$ plantarum ESI 144 in milk with $0.3 \%$ yeast extract. $30 \mathrm{~min}$ after starter and lactobacilli inoculation, Neutrase L (Novo España SA, Madrid, Spain) was added to vats 3 and 4 at a final concentration of 0.01 Anson units (AU) $/ L$ and rennet (8 mL Maxiren 1:15 000 strength v/v; Gist Brocades, Delft, the Netherlands) was added to each vat of milk. Coagulation took place in 40 $\mathrm{min}$. Curds were cut into 6- to 8-mm cubes and scalded at $37{ }^{\circ} \mathrm{C}$ for $15 \mathrm{~min}$. Four cheeses per vat were obtained, which were pressed for $20 \mathrm{~h}$, salted at $12{ }^{\circ} \mathrm{C}$ for $24 \mathrm{~h}$ in $15 \% \mathrm{NaCl}$ brine and ripened at $12^{\circ} \mathrm{C}$ for 60 days. 


\section{Microbiological analysis}

Curd and cheese homogenates and decimal dilutions were prepared as indicated by Fernandez del Pozo et al (1988). Total viable counts were determined in duplicate plates of plate count agar incubated at $30^{\circ} \mathrm{C}$ for $72 \mathrm{~h}$. Lactobacilli were determinated on duplicate plates of Rogosa Agar (Difco) incubated at $30^{\circ} \mathrm{C}$ for $72 \mathrm{~h}$ in anaerobiosis.

\section{Chemical analysis}

Cheese $\mathrm{pH}$ (in duplicate) and dry matter (in triplicate) were determined as previously described (Picon et al, 1995). N soluble at pH 4.6, in $12 \%$ TCA and in 1\% PTA were determined in duplicate from homogenates obtained from $20 \mathrm{~g}$ curd or cheese samples as previously described (Gaya et al, 1990), and expressed as percentages of total N. Residual casein fractions were determined in duplicate by PAGE and expressed as the percentage of the total amount of the respective casein fraction initially present in milk (Picon et al, 1995). Water soluble fractions of cheese were prepared according to Aston and Creamer (1986). Hydrophobic and hydrophilic peptides in the water soluble fraction were determined in duplicate by reverse-phase HPLC as described by Lau et al (1991), with a Beckman System Gold chromatograph (Beckman Instruments España SA, Madrid, Spain), equipped with a programmable solvent module 126 , a diode array detector module 168 and an autosampler 502. Detection was at wavelengths of 214 and $280 \mathrm{~nm}$. Peak with retention times from 8.5 to $14.6 \mathrm{~min}$ at $214 \mathrm{~nm}$ and from 5.6 to 14.6 $\mathrm{min}$ at $280 \mathrm{~nm}$ were considered to correspond to hydrophilic peptides and peaks with retention times from 14.6 to $20.5 \mathrm{~min}$ at both wavelengths to hydrophobic peptides. Results were expressed as units of chromatogram area per milligram of cheese dry matter (Picon et al, 1995).

\section{Textural measurements}

Cheese samples (six determinations per cheese) were compressed after 30 and 60 days of ripening using an Instron Compression Tester 4301 (Instron Lid, High Wycombe, Buckinghamshire, UK) as described by Fernandez del Pozo et al (1988). Apparent elastic modulus, calculated from the slope of the initial part of compression curves, was expressed in Newtons per square millimeter. Force at breaking point (breaking force) was expressed in Newtons. Hardness, defined as the work done on the cheese after $75 \%$ compression, was expressed in joules,

\section{Sensory evaluation}

Cheese bitterness, flavour quality and flavour intensity were evaluated after 30 and 60 days of ripening by 11 trained panellists on a 10-point scale as previously described (Fernandez del Pozo et al, 1988).

\section{Statistical treatment of results}

Analysis of variance was performed by using program BMDP8V (Department of Biomathematics, UCLA, Los Angeles, CA, USA). Means were compared using the least significant difference test at $P=0.05$ (Steel and Torrie, 1980).

\section{RESULTS AND DISCUSSION}

\section{Lactobacilli counts and cheese $\mathrm{pH}$}

Counts of lactobacilli were 8.6-8.7 log $\mathrm{CFU} / \mathrm{g}$ in 24-h cheeses made with added adjunct. Their levels increased to a maximum of 9.3-9.4 log CFU/g after 45 days of ripening, and decreased to $8.7-8.8 \mathrm{log}$ $\mathrm{CFU} / \mathrm{g}$ thereafter. In cheeses without added adjunct, lactobacilli attained mean values of 7.4-7.6 log CFU/g throughout the ripening period. No significant influence of the addition of BSNP on growth of lactobacilli during ripening was observed. Trépanier et al (1992a) found that lactobacilli reached levels of $8.0-9.0 \mathrm{log} C F U / g$ in 1 week Cheddar cheese with initial counts of 6.0-6.7 log CFU/g L casei subsp casei L2A, whereas in control cheese made without added lactobacilli counts of 8.0-9.0 log $\mathrm{CFU} / \mathrm{g}$ were not reached until week 10 . According to McSweeney et al (1994), numbers of lactobacilli in pasteurised milk cheese made without added lactobacilli increased to $10^{5}-10^{8} / \mathrm{g}$ after 30 weeks of ripening, whereas in cheese made with a mixture of mesophilic lactobacilli as adjunct they reached $10^{8}-10^{9} / \mathrm{g}$ after $2-3$ weeks 
and remained above $10^{8} / \mathrm{g}$ throughout the ripening period.

Cheese $\mathrm{pH}$ was significantly $(P<0.001)$ lower in cheese from milk with added $L$ plantarum ESI 144; the $\mathrm{pH}$ increased $(P<0.001)$ as cheese aged (table 1$)$. During early cheesemaking $(0-12 \mathrm{~h}) \mathrm{pH}$ values in cheese with added lactobacilli were $0.05-0.10$ units lower than in cheese without added lactobacilli, indicating that the adjunct metabolised lactose and produced lactic acid. In cheese without BSNP, no significant differences in $\mathrm{pH}$ between cheese with and without added lactobacilli were recorded from day 1 to day 15 , but $\mathrm{pH}$ was significantly lower in cheese with added lactobacilli from day 30 onwards. In cheeses with BSNP, $\mathrm{pH}$ was significantly lower in cheese with added lactobacilli than in cheese without added lactobacilli throughout the entire ripening period (table I).

L casei subsp casei CV1A and MIL2B added to milk ( 10 $10^{6} \mathrm{CFU} / \mathrm{mL}$ ) did not affect the development of acidity during Cheddar cheesemaking and ripening (Broome et al, 1990). However, in Cheddar cheese with added $L$ casei subsp casei $L 2 A\left(\sim 2 \times 10^{5}\right.$ $\mathrm{CFU} / \mathrm{mL}$ ), $\mathrm{pH}$ values after 1 month were significantly lower, with differences of 0.04 $0.12 \mathrm{pH}$ units (Trépanier et al, 1991a). The addition of live $(0.01 \%)$ and heat-shocked $(1 \%)$ L casei subsp casei L2A in cheeses made with BSNP also decreased cheese $\mathrm{pH}$ throughout the ripening period (Trépanier et al, 1992b).

Differences in cheese dry matter caused by milk inoculation with lactobacilli were not observed. On the contrary, BSNP addition $(P<0.01)$ and cheese ageing $(P<0.001)$ increased cheese dry matter (table I).

\section{Casein hydrolysis}

In cheeses made without added BSNP, degradation of both $\alpha_{\mathrm{s} 1}$ - and $\beta$-casein was significantly $(P<0.001)$ retarded by milk inoculation with $L$ plantarum and enhanced $(P<0.001)$ by cheese age. Differences in

Table I. Values of $\mathrm{pH}^{1}$ and dry matter ${ }^{2}$ in cheeses manufactured with L plantarum ESI 144 and Bacillus subtilis neutral proteinase (BSNP).

Valeurs du $\mathrm{pH}$ et de l'extrait sec des fromages fabriqués avec et sans addition de L plantarum ESI 144 et de la protéinase neutre de Bacillus subtilis.

\begin{tabular}{lccccc}
\hline & \multicolumn{2}{c}{ OAU/L of BSNP } & \multicolumn{2}{c}{0.01 AU/L of BSNP } \\
& Days & $\begin{array}{c}0 \% \\
\text { L plantarum }\end{array}$ & $\begin{array}{c}1 \% \\
\text { L plantarum }\end{array}$ & $\begin{array}{c}0 \% \\
\text { L plantarum }\end{array}$ & $\begin{array}{c}1 \% \\
\text { L plantarum }\end{array}$ \\
\hline $\mathrm{pH}$ & 1 & 4.90 & 4.91 & 4.91 & $4.88^{\mathrm{a}}$ \\
& 15 & 4.89 & 4.88 & 4.93 & $4.90^{\mathrm{a}}$ \\
& 30 & 4.99 & $4.94^{\mathrm{a}}$ & 4.99 & $4.87^{\mathrm{a}}$ \\
& 45 & 5.18 & $5.01^{\mathrm{a}}$ & 5.21 & $4.99^{\mathrm{a}}$ \\
Dry matter & 60 & 5.19 & $5.09^{\mathrm{a}}$ & 5.21 & $5.09^{\mathrm{a}}$ \\
& 1 & 48.29 & 48.26 & 46.67 & 47.53 \\
& 15 & 54.07 & 52.49 & 53.96 & 54.33 \\
& 30 & 56.10 & 56.84 & 57.05 & 57.03 \\
& 45 & 57.12 & 56.42 & 58.24 & 59.07 \\
& 60 & 57.92 & 59.94 & 59.05 & 58.95 \\
\hline
\end{tabular}

\footnotetext{
${ }_{1}^{1}$ Means of duplicate determinations in two cheesemaking trials. ${ }^{2}$ Means of triplicate determinations in two cheesemaking trials. "Significantly $(P<0.05)$ different from the respective value in cheese made without $L$ plantarum.

${ }^{1}$ Moyenne d'une double détermination lors de deux essais de fabrication de fromage. ${ }^{2}$ Moyenne d'une triple détermination lors de deux essais de fabrication de fromage. ${ }^{a}$ Valeur significativement différente $(\mathrm{p}<0,05)$ de celle du fromage fabriqué sans $\mathrm{L}$ plantarum.
} 
residual $\alpha_{s 1^{-}}$and $\beta$-casein caused by added lactobacilli were already significant after $24 \mathrm{~h}$ (table II). The $\mathrm{pH}$ value was approximately 0.1 unit lower in cheese with added lactobacilli than in cheese without added lactobacilli from $6 \mathrm{~h}$ to $10 \mathrm{~h}$ after milk inoculation, a fact which would reduce the activity of plasmin, thus hindering proteolysis in the former cheese. At the end of the ripening period, both residual $\alpha_{s 1}$ - and $\beta$-casein were still significantly higher in cheese with added lactobacilli.

Addition of BSNP to milk significantly $(P<0.001)$ enhanced degradation of $\alpha_{s 1^{-}}$ and $\beta$-casein (table II). In cheeses made with added BSNP, milk inoculation with $L$ plantarum retarded degradation of $\alpha_{s 1}$ casein $(P<0.01)$ and $\beta$-casein $(P<0.001)$. Residual caseins decreased significantly $(P<0.001)$ as cheese aged. In $24 \mathrm{~h}$ cheese, $\alpha_{s 1^{-}}$and $\beta$-caseins were significantly higher if lactobacilli had been added to milk, because of the lower $\mathrm{pH}$ value from $2 \mathrm{~h}$ to $10 \mathrm{~h}$ after milk inoculation in cheese with added lactobacilli. No differences in residual $\alpha_{s 1}$-casein between cheese with and without added lactobacilli were detected from day 15 onwards. However, residual $\beta$-casein remained significantly higher in cheese with added lactobacilli throughout the entire ripening period (table II).

Rennet and plasmin are responsible for the initial hydrolysis of the major caseins in cheese to polypeptides that are further hydrolysed by proteinases and peptidases. Plasmin dissociates from the micelles as the $\mathrm{pH}$ is reduced and hydrolyses $\beta$-casein in preference to $\alpha_{s 1}$-casein (Fox, 1989). In our work, major differences in casein breakdown were detected during the first $24 \mathrm{~h}$, probably due to the lower $\mathrm{pH}$ values in cheese with added lactobacilli which reduced the activity of plasmin, and of BSNP when added. Values of $\mathrm{pH}$ in the range 5.05.1 were considered unfavourable for BSNP activity in Manchego cheese, as the optimum $\mathrm{pH}$ of this proteinase is close to neutrality (Picon et al, 1995). No differences in casein degradation were observed in cheese with addition of heattreated $L$ helveticus CNRZ 303 (Ardö and Pettersson, 1988) or with mesophilic lac-

Table II. Residual $\alpha_{s 1}$ - and $\beta$-casein ${ }^{1}$ in cheeses manufactured with $L$ plantarum ESI 144 and Bacillus subtilis neutral proteinase (BSNP).

Caséines $\alpha_{s 1}$ et $\beta$ résiduelles dans des fromages fabriqués avec et sans addition de $L$ plantarum ESI 144 et de la protéinase neutre de Bacillus subtilis.

$$
\text { O AU/L of BSNP } \quad 0.01 \mathrm{AU} / \mathrm{L} \text { of BSNP }
$$

\begin{tabular}{lccccc} 
Casein & Days & $\begin{array}{c}0 \% \\
\text { L plantarum }\end{array}$ & $\begin{array}{c}1 \% \\
\text { L plantarum }\end{array}$ & $\begin{array}{c}0 \% \\
\text { L plantarum }\end{array}$ & $\begin{array}{c}1 \% \\
\text { L plantarum }\end{array}$ \\
\hline$\alpha_{\text {s1-casein }}$ & 1 & 86.1 & $97.0^{\mathrm{a}}$ & 68.6 & $78.7^{\mathrm{a}}$ \\
& 15 & 56.5 & 61.8 & 43.7 & 47.2 \\
& 30 & 42.4 & $51.5^{\mathrm{a}}$ & 39.5 & 39.2 \\
& 45 & 36.8 & $49.1^{\mathrm{a}}$ & 31.6 & 32.3 \\
$\beta$-casein & 60 & 26.0 & $39.5^{\mathrm{a}}$ & 27.2 & 29.5 \\
& 1 & 84.6 & $94.4^{\mathrm{a}}$ & 46.8 & $59.9^{\mathrm{a}}$ \\
& 15 & 77.4 & 80.5 & 35.1 & $42.7^{\mathrm{a}}$ \\
& 30 & 70.5 & 72.8 & 31.8 & $40.2^{\mathrm{a}}$ \\
& 45 & 63.2 & $71.4^{\mathrm{a}}$ & 28.4 & $37.2^{\mathrm{a}}$ \\
& 60 & 56.7 & $64.2^{\mathrm{a}}$ & 25.3 & $31.8^{\mathrm{a}}$ \\
\hline
\end{tabular}

\footnotetext{
${ }^{1}$ Means of duplicate determinations in two cheesemaking trials, expressed as percentage of $\alpha_{s 1}$-or $\beta$-casein contents of milk. ${ }^{a}$ Significantly $(P<0.05)$ different from the respective value in cheese made without $L$ plantarum.

' Moyenne d'une double détermination lors de deux essais de fabrication de fromage, exprimés en pourcentage de caséines $\alpha_{s 1}$ ou $\beta$ dans le lait. ${ }^{a}$ Valeur significativement différente $(p<0,05)$ de celle du fromage fabriqué sans L plantarum.
} 
tobacilli as adjunct (McSweeney et al, 1994). However, L plantarum 99 appeared to initially inhibit the action of rennet by slowing down its process of casein degradation in Cheddar cheese made from milk with $10^{5}$ lactobacilli/mL (Lemieux et al, 1989). No differences in casein degradation were found in Comté cheeses manufactured with different strains of $L$ helveticus and $L$ delbrueckii subsp lactis (Bouton et al, 1994).

\section{Formation of soluble $\mathrm{N}$}

As expected, $\mathrm{N}$ soluble at $\mathrm{pH} 4.6$, in TCA and in PTA increased $(P<0.001)$ as cheese aged. In cheese made without BSNP, the formation of $\mathrm{pH} 4.6$ soluble $\mathrm{N}$, TCA soluble $\mathrm{N}$ and PTA soluble $\mathrm{N}$ throughout ripening (table III) was reduced
$(P<0.001)$ by lactobacilli addition, probably because of the lower $\mathrm{pH}$ and the delayed casein hydrolysis. $\mathrm{N}$ soluble at $\mathrm{pH} 4.6$ was significantly lower in cheese with added lactobacilli than in cheese without added lactobacilli from day $30, \mathrm{~N}$ soluble in TCA from day 45 and $\mathrm{N}$ soluble in PTA from day 15 .

Addition of BSNP to milk significantly $(P<0.001)$ enhanced the formation of $\mathrm{pH}$ 4.6 soluble $\mathrm{N}$, TCA soluble $\mathrm{N}$ and PTA soluble N (table III). In BSNP cheeses, addition of $L$ plantarum decreased $(P<0.001)$ the formation of $\mathrm{pH} 4.6$ soluble $\mathrm{N}$ during the second month of ripening, as the lower $\mathrm{pH}$ of cheese with added lactobacilli from day 30 to day 60 would reduce the activity of caseinolytic enzymes. However, TCA soluble $\mathrm{N}$ was higher $(P<0.01)$ in cheese with added lactobacilli, which would be di-

Table III. Soluble N fractions ${ }^{1}$ in cheeses manufactured with L plantarum ESI 144 and Bacillus subtilis neutral proteinase (BSNP).

Fractions d'azote soluble dans des fromages fabriqués avec et sans addition de L plantarum ESI 144 et de la protéinase neutre de Bacillus subtilis.

\begin{tabular}{lccccc}
\hline & \multicolumn{2}{c}{ O AU/L of BSNP } & \multicolumn{2}{c}{0.01 AU/L of BSNP } \\
N soluble & Days & $\begin{array}{c}0 \% \\
\text { L plantarum }\end{array}$ & $\begin{array}{c}1 \% \\
\text { L plantarum }\end{array}$ & $\begin{array}{c}0 \% \\
\text { L plantarum }\end{array}$ & $\begin{array}{c}1 \% \\
\text { L plantarum }\end{array}$ \\
\hline At pH 4.6 & 1 & 10.39 & $11.71^{\mathrm{a}}$ & 18.62 & 19.02 \\
& 15 & 11.88 & 12.42 & 20.12 & 20.43 \\
& 30 & 15.05 & $13.53^{\mathrm{a}}$ & 21.41 & 21.78 \\
& 45 & 20.90 & $14.68^{\mathrm{a}}$ & 25.74 & $23.73^{\mathrm{a}}$ \\
& 60 & 22.00 & $16.37^{\mathrm{a}}$ & 28.04 & $24.88^{\mathrm{a}}$ \\
In TCA & 1 & 3.79 & $4.26^{\mathrm{a}}$ & 5.89 & $4.68^{\mathrm{a}}$ \\
& 15 & 5.77 & $6.70^{\mathrm{a}}$ & 8.19 & $8.57^{\mathrm{a}}$ \\
& 30 & 6.88 & $7.63^{\mathrm{a}}$ & 10.05 & $11.05^{\mathrm{a}}$ \\
& 45 & 10.60 & $8.67^{\mathrm{a}}$ & 13.31 & $13.79^{\mathrm{a}}$ \\
& 60 & 10.87 & $9.08^{\mathrm{a}}$ & 14.83 & 15.09 \\
& 1 & 1.68 & 1.73 & 2.33 & $1.96^{\mathrm{a}}$ \\
& 15 & 2.42 & $2.05^{\mathrm{a}}$ & 3.81 & 3.92 \\
& 30 & 3.60 & $3.33^{\mathrm{a}}$ & 5.38 & $5.06^{\mathrm{a}}$ \\
& 45 & 5.32 & $4.35^{\mathrm{a}}$ & 6.75 & $6.04^{\mathrm{a}}$ \\
& 60 & 5.68 & $4.64^{\mathrm{a}}$ & 8.21 & $7.90^{\mathrm{a}}$ \\
\hline
\end{tabular}

\footnotetext{
${ }^{1}$ Means of duplicate determinations in two cheesemaking trials, expressed as percentage of total N.

a Significantly $(P<0.05)$ different from the respective value in cheese made without $L$ plantarum.

1 Moyenne d'une double détermination lors de deux essais de fabrication de fromage, exprimés en pourcentage du total $N$. ${ }^{a}$ Valeur significativement différente $(\mathrm{p}<0,05)$ de celle du fromage fabriqué sans L plantarum.
} 
rectly responsible for this enhanced proteolytic activity. Finally, PTA soluble $\mathrm{N}$ was lower $(P<0.001)$ in cheese with added lactobacilli, because of an adverse influence of the lower $\mathrm{pH}$ on peptidolytic activity in cheese and also probably due to the uptake of small peptides and amino acids by lactobacilli.

Increased levels of free amino acids were found after 2 months in cheese made with $10^{5} \mathrm{~L}$ plantarum $99 / \mathrm{mL}$ (Puchades et al, 1989 ), or with heat-treated cells of $L$ helveticus CNRZ 303 (Ardö and Pettersson, 1988; Ardö et al, 1989). L casei subsp casei L2A also produced higher levels of amino acids during Cheddar cheese ripening (Lemieux et al, 1989; Puchades et al, 1989). A greater concentration of amino acid $\mathrm{N}$ was detected in Cheddar cheese with mesophilic lactobacilli as starter adjunct (McSweeney et al, 1994). Contrary to these results, Ardö et al (1989) showed no changes in $\mathrm{N}$ soluble at $\mathrm{pH} 4.6$ and $\mathrm{N}$ soluble in PTA during 13 weeks of ripening in low-fat cheeses made with viable $L$ helveticus cells.

Lower $\mathrm{pH}$ values detected in our work for cheeses with added lactobacilli could reduce peptide hydrolysis, as reduced aminopeptidase activity has been observed in a more acidic environment (Frey et al, 1986, Cholette and McKellar, 1990). Moreover, large numbers of viable cells added to cheese could incorporate liberated small peptides and amino acids into cellular components during growth (Frey et al, 1986), thus reducing the concentration of $\mathrm{N}$ soluble in PTA detected by analytical methods.

\section{Hydrophobic and hydrophilic peptides}

The level of hydrophobic peptides in cheese is considered to be related to bitter flavour defect. A high proportion of hydrophobic peptides was present in extracts of bitter Cheddar cheese (Champion and Stanley, 1982).
In cheeses made without BSNP, the amount of hydrophobic and hydrophilic peptides measured at $214 \mathrm{~nm}$ and $280 \mathrm{~nm}$ (tables IV, V) was lowered $(P<0.001)$ by lactobacilli addition with significant differences from day 1 , and increased by cheese age $(P<0.001)$. However, the hydrophobic:hydrophilic ratio was higher $(P<0.001)$ in cheeses with $L$ plantarum and decreased $(P<0.001)$ as cheese aged. In cheeses made without BSNP, the level of hydrophobic peptides in 60-day cheese determined at 214 and $280 \mathrm{~nm}$ was reduced by $9.4 \%$ and $7.8 \%$, respectively, by milk inoculation with L plantarum ESI 144.

Addition of BSNP to milk significantly $(P<0.001)$ enhanced the formation of hydrophobic and hydrophilic peptides and increased their ratio, at both detection wavelengths (tables IV, V). In cheeses elaborated with BSNP, hydrophobic and hydrophilic peptides at $214 \mathrm{~nm}$ and their ratio (table IV) were significantly reduced $(P<0.001)$ by milk inoculation with $L$ plantarum. Hydrophobic and hydrophilic peptides at $214 \mathrm{~nm}$ increased $(P<0.001)$ and their ratio decreased $(P<0.001)$ as cheese aged. Hydrophobic and hydrophilic peptides determined at $280 \mathrm{~nm}$ (table V) were significantly $(P<0.001)$ reduced by milk inoculation with $L$ plantarum. On the contrary, the hydrophobic:hydrophilic ratio at $280 \mathrm{~nm}$ was increased $(P<0.01)$ by lactobacilli addition. Hydrophobic peptides increased from day 1 to day 30 , whereas hydrophilic peptides increased $(P<0.001)$ their levels until day 60 . The hydrophobic:hydrophilic ratio decreased $(P<0.001)$ throughout ripening. In cheeses made with BSNP, the level of hydrophobic peptides determined at 214 and $280 \mathrm{~nm}$ after 60 days was reduced by 20.6 and $20.7 \%$, respectively, by milk inoculation with L plantarum ESI 144.

\section{Textural characteristics}

In cheeses made without addition of BSNP, the apparent elastic modulus, breaking 
force and hardness determined from the compression curves obtained with the Instron tester (table VI) were significantly $(P<0.001)$ increased by addition of $L$ plantarum ESI 144 and by cheese age. Residual $\alpha_{s 1}$-casein plays a crucial role in the stability of the cheese protein network (Creamer and Olson, 1982). As the degradation of $\alpha_{s 1}$-casein in cheeses made without BSNP was retarded by the addition of lactobacilli, a firmer texture was obtained.

The addition of BSNP to milk gave rise to a cheese with softer $(P<0.001)$ texture (table VI). In BSNP cheese, milk inoculation with lactobacilli resulted in higher $(P<0.01)$ breaking force and hardness, whereas no significant differences in apparent elastic modulus were detected. However, after 60 days of ripening, textural characteristics of BSNP cheeses without or with added lactobacilli did not differ significantly.

\section{Sensory characteristics}

In cheeses made without added BSNP, bitterness and flavour intensity were not influenced by milk inoculation with $L$ plantarum, whereas flavour quality was adversely $(P<0.05)$ affected (table VII). Bitterness score was not influenced by cheese age,

Table IV. Hydrophobic and hydrophilic peptides ${ }^{1}$ and hydrophobic:hydrophilic ratio in the water soluble fraction of cheeses manufactured with L plantarum ESI 144 and Bacillus subtilis neutral proteinase (BSNP) determined by RP-HPLC at a wavelength of $214 \mathrm{~nm}$.

Peptides hydrophobes et hydrophiles et rapport hydrophobes:hydrophiles dans la fraction hydrosoluble des fromages fabriqués avec et sans addition de L plantarum ESI 144 et de la protéinase neutre de Bacillus subtilis déterminés par CLHP en phase inverse à une longeur d'onde de $214 \mathrm{~nm}$.

\begin{tabular}{lccccc}
\hline & \multicolumn{2}{c}{ O AU/L of BSNP } & \multicolumn{2}{c}{0.01 AU/L of $B S N P$} \\
Peptides & Days & $\begin{array}{c}0 \% \\
\text { L plantarum }\end{array}$ & $\begin{array}{c}1 \% \\
\text { L plantarum }\end{array}$ & $\begin{array}{c}0 \% \\
\text { L plantarum }\end{array}$ & $\begin{array}{c}1 \% \\
\text { L plantarum }\end{array}$ \\
\hline Hydrophobic & 1 & 42.17 & $31.65^{\mathrm{a}}$ & 91.92 & $74.43^{\mathrm{a}}$ \\
& 15 & 75.29 & $61.14^{\mathrm{a}}$ & 120.49 & $114.39^{\mathrm{a}}$ \\
& 30 & 87.90 & $71.49^{\mathrm{a}}$ & 153.61 & $134.21^{\mathrm{a}}$ \\
& 45 & 96.80 & $73.48^{\mathrm{a}}$ & 137.02 & $121.94^{\mathrm{a}}$ \\
& 60 & 98.53 & $89.25^{\mathrm{a}}$ & 173.68 & $137.82^{\mathrm{a}}$ \\
Hydrophilic & 1 & 46.92 & $34.81^{\mathrm{a}}$ & 78.44 & 73.50 \\
& 15 & 98.61 & $81.50^{\mathrm{a}}$ & 153.14 & 154.51 \\
& 30 & 139.60 & $109.39^{\mathrm{a}}$ & 238.26 & $203.59^{\mathrm{a}}$ \\
& 45 & 171.18 & $123.89^{\mathrm{a}}$ & 230.20 & 231.74 \\
& 60 & 195.75 & $163.98^{\mathrm{a}}$ & 307.89 & $263.85^{\mathrm{a}}$ \\
& 1 & 0.90 & 0.91 & 1.19 & $1.02^{\mathrm{a}}$ \\
& 15 & 0.77 & 0.76 & 0.79 & $0.74^{\mathrm{a}}$ \\
& 30 & 0.63 & $0.66^{\mathrm{a}}$ & 0.65 & 0.66 \\
& 45 & 0.56 & $0.59^{\mathrm{a}}$ & 0.60 & $0.53^{\mathrm{a}}$ \\
& 60 & 0.51 & $0.55^{\mathrm{a}}$ & 0.56 & $0.52^{\mathrm{a}}$ \\
\hline
\end{tabular}

\footnotetext{
${ }^{1}$ Means of duplicate determinations in two cheesemaking trials, expressed as chromatogram area units per milligram of dry cheese.

${ }^{a}$ Significantly $(P<0.05)$ different from the respective value in cheese made without $L$ plantarum.

'Moyenne d'une double détermination lors de deux essais de fabrication de fromage, exprimés en unités chromatographiques/mg de fromage sec.

a Valeur significativement différente $(\mathrm{p}<0,05)$ de celle du fromage fabriqué sans $\mathrm{L}$ plantarum.
} 
but flavour quality and flavour intensity increased $(P<0.05)$ from day 30 to day 60 .

Addition of BSNP to milk significantly $(P<0.001)$ increased cheese bitterness as well as flavour intensity, but it did not affect flavour quality. In BSNP cheeses, milk inoculation with $L$ plantarum significantly $(P<0.05)$ reduced bitterness caused by the proteinase. This fact could be related to the lower levels of hydrophobic peptides in the water soluble fraction detected at 214 and $280 \mathrm{~nm}$ in cheeses made with BSNP from milk to which $L$ plantarum had been added, compared with BSNP cheeses with no added lactobacilli (tables IV, V). High correlation coefficients between bitterness scores and level of hydrophobic peptides at 214 or $280 \mathrm{~nm}$ were obtained for pasteurised milk cheese (Gomez et al, unpublished results). Peptidase activity of lactobacilli in BSNP cheeses would be responsible for higher levels of TCA soluble $\mathrm{N}$ in cheese with added lactobacilli than in the respective cheese without added lactobacilli from day 15 onwards (table III).

Bartels et al (1987a) related the reduction in cheese bitterness to lower concentrations of bitter peptides separated by gel permeation chromatography. Removal of bitter taste from slurries of Cheddar cheese curds was associated with a decrease in hydrophobic peptides, determined by RP-

Table V. Hydrophobic and hydrophilic peptides ${ }^{1}$ and hydrophobic:hydrophilic ratio in the water soluble fraction of cheeses manufactured with $L$ plantarum ESI 144 and Bacillus subtilis neutral proteinase (BSNP) determined by RP-HPLC at a wavelength of $280 \mathrm{~nm}$.

Peptides hydrophobes et hydrophiles ${ }^{1}$ et relation hydrophobes:hydrophiles dans la fraction hydrosoluble des fromages fabriqués avec et sans addition de L plantarum ESI 144 et de la protéinase neutre de Bacillus subtilis déterminés par CLHP en phase inverse à une longeur d'onde de $280 \mathrm{~nm}$.

$$
0 \text { AU/L of BSNP } \quad 0.01 \mathrm{AU} / \mathrm{L} \text { of BSNP }
$$

\begin{tabular}{lccccc} 
Peptides & Days & $\begin{array}{c}0 \% \\
\text { L plantarum }\end{array}$ & $\begin{array}{c}1 \% \\
\text { L plantarum }\end{array}$ & $\begin{array}{c}0 \% \\
\text { L plantarum }\end{array}$ & $\begin{array}{c}1 \% \\
\text { L plantarum }\end{array}$ \\
\hline Hydrophobic & 1 & 0.62 & $0.38^{\mathrm{a}}$ & 1.58 & $1.39^{\mathrm{a}}$ \\
& 15 & 1.01 & $0.83^{\mathrm{a}}$ & 2.30 & $2.10^{\mathrm{a}}$ \\
& 30 & 1.18 & $0.87^{\mathrm{a}}$ & 2.57 & $2.42^{\mathrm{a}}$ \\
& 45 & 1.17 & $0.95^{\mathrm{a}}$ & 2.34 & $1.92^{\mathrm{a}}$ \\
Hydrophilic & 60 & 1.15 & $1.06^{\mathrm{a}}$ & 2.41 & $1.91^{\mathrm{a}}$ \\
& 1 & 4.51 & $2.61^{\mathrm{a}}$ & 5.16 & $3.98^{\mathrm{a}}$ \\
& 15 & 5.19 & $3.73^{\mathrm{a}}$ & 7.12 & $6.45^{\mathrm{a}}$ \\
& 30 & 6.55 & $4.49^{\mathrm{a}}$ & 11.51 & $9.13^{\mathrm{a}}$ \\
Ratio & 45 & 8.12 & $4.90^{\mathrm{a}}$ & 11.64 & $10.13^{\mathrm{a}}$ \\
& 60 & 7.78 & $6.91^{\mathrm{a}}$ & 14.06 & $12.28^{\mathrm{a}}$ \\
& 1 & 0.14 & $0.15^{\mathrm{a}}$ & 0.31 & $0.35^{\mathrm{a}}$ \\
& 15 & 0.20 & $0.22^{\mathrm{a}}$ & 0.32 & 0.31 \\
& 30 & 0.19 & 0.19 & 0.23 & $0.27^{\mathrm{a}}$ \\
& 45 & 0.14 & $0.19^{\mathrm{a}}$ & 0.20 & $0.19^{\mathrm{a}}$ \\
& 60 & 0.15 & $0.16^{\mathrm{a}}$ & 0.17 & $0.16^{\mathrm{a}}$ \\
\hline
\end{tabular}

\footnotetext{
${ }^{1}$ Means of duplicate determinations in two cheesemaking trials, expressed as chromatogram area units per milligram of dry cheese.

${ }^{a}$ Significantly $(P<0.05)$ different from the respective value in cheese made without $L$ plantarum.

${ }^{1}$ Moyenne d'une double détermination lors de deux essais de fabrication de fromage, exprimés en unités chromatographiques/mg de fromage sec.

a Valeur significativement différente $(\mathrm{p}<0,05)$ de celle du fromage fabriqué sans $\mathrm{L}$ plantarum.
} 
Table VI. Textural characteristics ${ }^{1}$ of cheeses manufactured with $L$ plantarum ESI 144 and Bacillus subtilis neutral proteinase (BSNP).

Caractéristiques texturales ${ }^{1}$ des fromages fabriqués avec et sans addition de L plantarum ESI 144 et de la protéinase neutre de Bacillus subtilis.

$O A U / L$ of $B S N P$

$0.01 A U / L$ of BSNP

Days

$0 \%$

L plantarum

$1 \%$

$0 \%$

L plantarum

\subsection{7}

0.572

60

elastic

modulus

$1 \%$

L plantarum

\begin{tabular}{llllll}
$\begin{array}{l}\text { Breaking } \\
\text { force }\end{array}$ & 30 & 18.62 & $27.26^{\mathrm{a}}$ & 14.94 & $19.26^{\mathrm{a}}$ \\
& 60 & 21.83 & $29.56^{\mathrm{a}}$ & 16.14 & 17.55 \\
Hardness & 30 & 0.189 & $0.251^{\mathrm{a}}$ & & 0.142 \\
& 60 & 0.237 & $0.300^{\mathrm{a}}$ & 0.183 & $0.193^{\mathrm{a}}$ \\
\hline
\end{tabular}

${ }^{1}$ Means of six determinations per cheese in two cheesemaking trials.

a Significantly $(P<0.05)$ different from the respective value in cheese made without $L$ plantarum.

${ }^{1}$ Moyenne de six déterminations par fromage lors de deux essais de fabrication de fromage.

a Valeur significativement différente $(\mathrm{p}<0,05)$ de celle du fromage fabriqué sans $\mathrm{L}$ plantarum.

Table VII. Sensory characteristics ${ }^{1}$ of cheeses manufactured with $L$ plantarum ESI 144 and Bacillus subtilis neutral proteinase (BSNP).

Caractéristiques sensorielles ${ }^{1}$ des fromages fabriqués avec et sans addition de L plantarum ESI 144 et de la protéinase neutre de Bacillus subtilis.

\section{$0 A U / L$ of BSNP $\quad 0.01 A U / L$ of BSNP}

\begin{tabular}{lccccc} 
& Days & $\begin{array}{c}0 \% \\
\text { L plantarum }\end{array}$ & $\begin{array}{c}1 \% \\
\text { L plantarum }\end{array}$ & $\begin{array}{c}0 \% \\
\text { L plantarum }\end{array}$ & $\begin{array}{c}1 \% \\
\text { L plantarum }\end{array}$ \\
\hline Bitterness & 30 & 0.65 & 0.74 & 2.37 & $1.55^{\mathrm{a}}$ \\
& 60 & 0.15 & 0.26 & 1.00 & 0.62 \\
Flavour & 30 & 5.47 & 5.15 & 4.41 & 4.70 \\
quality & 60 & 6.38 & $5.45^{\mathrm{a}}$ & 6.05 & 5.64 \\
& & & & & \\
Flavour & 30 & 4.89 & 5.00 & 5.65 & 5.75 \\
intensity & 60 & 5.57 & 5.22 & 6.54 & 5.92
\end{tabular}

\footnotetext{
${ }^{1}$ Means of scores from 11 trained panellists in two cheesemaking trials using a 10-point scale.

a Significantly $(P<0.05)$ different from the respective value in cheese made without $L$ plantarum.

${ }^{1}$ Moyenne des résultats de 11 examinateurs, exprimés sur une échelle de 10 points, lors de deux essais de fabrication de fromage.

a Valeur significativement différente $(\mathrm{p}<0,05)$ de celle du fromage fabriqué sans L plantarum.
} 
HPLC (Cliffe and Law, 1990). However, reduced bitterness in Emmental cheese attributed to the aminopeptidase activity of $L$ helveticus $L 1$ was not related with casein degradation or with differences in levels of small peptides and free amino acids (Prost and Chamba, 1994).

In BSNP cheeses, no significant effect of milk inoculation with lactobacilli on flavour quality was detected. Flavour quality increased significantly $(P<0.001)$ from day 30 to day 60 . Milk inoculation with lactobacilli did not decrease flavour intensity of BSNP cheeses, despite the higher level of residual caseins found in cheeses made with $L$ plantarum as adjunct. Flavour intensity scores did not increase significantly in BSNP cheeses from day 30 to day 60 (table VII).

Lysis of lactobacilli could be a limiting factor in the rate of peptidolysis under the cheesemaking and ripening conditions used in the present work. Maybe 60 days is a too short ripening period for natural lysis of the lactobacilli to occur in cheese. The stimulating effect of a heat treatment on release of enzyme from lactobacilli was shown to be of a great importance in assuring the desired aminopeptidolysis early in cheese maturation (Ardö et al, 1989). Increased lactic acid bacteria lysis has been associated with higher concentrations of amino acids in Cheddar cheese (Crow et al, 1995), being peptidase leakage an essential event for efficient peptide hydrolysis in cheese.

The combined action of Bacillus subtilis neutral proteinase and of selected strains of lactobacilli may accelerate cheese ripening without enhancing bitterness defect. The use of $L$ plantarum ESI 144 cultures attenuated by heat or freeze-shocking might be required to reduce acidifying activity, maintaining a favourable impact on sensory attributes like flavour quality or intensity because of the increase in the debittering activity present in cheese.

\section{ACKNOWLEDGMENTS}

Financial support from CICYT project ALI930064 and technical assistance of M de Paz and C Serrano are gratefully acknowledged.

\section{REFERENCES}

Ardö Y, Pettersson H-E (1988) Accelerated cheese ripening with heat treated cells of Lactobacillus helveticus and a commercial proteolytic enzyme. J Dairy Res 55, 239-245

Ardö Y, Larsson P-O, Lindmark Månsson $\mathrm{H}$, Hedenberg A (1989) Studies of peptidolysis during early maturation and its influence on low-fat cheese quality. Milchwissenschaft 44, 485-490

Arora G, Lee BH (1990) Comparative studies on peptidases of Lactobacillus casei subspecies. J Dairy Sci 73, 274-279

Aston JW, Creamer LK (1986) Contribution of the components of the water-soluble fraction to the flavour of Cheddar cheese. NZJ Dairy Sci Techno/21, 229-248

Bartels HJ, Johnson ME, Olson NF (1987a) Accelerated ripening of Gouda cheese. 1. Effect of heat-shocked thermophilic lactobacilli and streptococci on proteolysis and flavor development. Milchwissenschaft 42, $83-88$

Bartels HJ, Jahnson ME, Olson NF (1987b) Accelerated ripening of Gouda cheese. 2. Effect of freezeshocked Lactobacillus helveticus on proteolysis and flavor development. Milchwissenschaft 42, 139-144

Bouton Y, Guyot P, Dasen A, Grappin R (1994) Activitè protéolytique de souches de lactobacilles thermophiles isolées de levains et de Comté. II. Applications en sites industriels. Lait 74, 33-46

Broome MC, Krause DA. Hickey MW (1990) The use of non-starter lactobacilli in Cheddar cheese manufacture. Aust J Dairy Technol 45, 67-73

Champion HM, Stanley DW (1982) HPLC separation of bitter peptides from Cheddar cheese. Can Inst Food Sci Technol J 15, 283-288

Cholette H, McKellar RC (1990) Influence of $\mathrm{pH}$ on the properties of Lactobacillus helveticus aminopeptidase. J Dairy Sci 73, 2278-2286

Cliffe AJ, Law BA (1990) Peptide composition of enzyme-treated Cheddar cheese slurries determined by reverse phase high performance liquid chromatography. Food Chem $36,73-80$

Creamer LK, Olson NF (1982) Rheological evaluation of maturing Cheddar cheese. J Food Sci 47, 631636,646

Crow VL, Martley FJ, Coolbear T, Roundhill SJ (1995) The influence of phage-assisted lysis of Lactococcus lactis subsp lactis MLB on Cheddar cheese ripening. Int Dairy J 5, 451-472

El Soda M. Desmazeaud MJ, Aboudonia S, Kamal N (1981) Acceleration of cheese ripening by the addition of whole cells or cell free extracts from Lactobacillus casei to cheese curd. Milchwissenschaft 36, 140-142 
Fernandez del Pozo B, Gaya P, Medina M, RodriguezMarin MA, Nuñez M (1988) Changes on chemical and rheological characteristics of La Serena ewes' milk cheese during ripening. J Dairy Res $55,457-$ 464

Fox PF (1989) Proteolysis during cheese manufacture and ripening. J Dairy Sci 72, 1379-1400

Frey JP, Marth EH, Johnson ME, Olson NF (1986) Heatand freeze-shocking cause changes in peptidase and protease activity of Lactobacillus helveticus. Milchwissenschaft 41, 681-685

Gaya P, Medina M, Rodriguez-Marin MA, Nuñez M (1990) Accelerated ripening of ewes' milk Manchego cheese: the effect of elevated ripening temperatures. J Dairy Sci 73, 26-32

Gomez MJ, Gaya P, Nuñez M, Medina M (1996) Debittering activity of peptidases from selected lactobacilli strains in model cheeses. Milchwissenschaft, 51, 315-319

Lau KY, Barbano DM, Rasmussen RR (1991) Influence of pasteurization of milk on protein breakdown in Cheddar cheese during aging. J Dairy Sci 74, 727740

Lemieux L, Puchades R, Simard RE (1989) Size-exclusion HPLC separation of bitter and astringent fractions from Cheddar cheese made with added $\mathrm{Lac}$ tobacillus strains to accelerate ripening. J Food Sci $54,1234-1237$

McSweeney PLH, Walsh EM, Fox PF, Cogan TM, Drinan FD, Castelo-Gonzalez M (1994) A procedure for the manufacture of Cheddar cheese under controlled bacteriological conditions and the effect of adjunct lactobacilli on cheese quality. Ir J Agric Food Res 33, 183-192

Park SY, Gibbs BF, Lee BH (1995) Effects of crude enzyme of Lactobacillus casei LLG on water-soluble peptides of enzyme-modified cheese. Food Res Int $28,43-49$
Picon A, Gaya P, Medina M, Nuñez M (1995) The effect of liposome-encapsulated Bacillus subtilis neutral proteinase on Manchego cheese ripening. $J$ Dairy Sci $78,1238-1247$

Prost F, Chamba JF (1994) Effect of aminopeptidase activity of thermophilic lactobacilli on Emmental cheese characteristics. J Dairy Sci 77, 24-33

Puchades R, Lemieux L, Simard RE (1989) Evolution of free aminoacids during the ripening of Cheddar cheese containing added lactobacilli strains. J Food Sci 54, 885-888, 946

Steel RGD, Torrie JH (1980) Principles and Procedures of Statistics, a Biometrical Approach, 2nd edn (C Napier, JW Maisel, eds) McGraw-Hill International Book Co, New York

Trépanier G, Simard RE, Lee BH (1991a) Effect of added lactobacilli on composition and texture of Cheddar cheese during accelerated maturation. J Food Sci 56, 696-700

Trépanier G, Simard RE, Lee BH (1991b) Lactic acid bacteria relation to accelerated maturation of Cheddar cheese. J Food Sci 56, 1238-1240, 1254

Trépanier G, El Abboudi M, Lee BH, Simard RE (1992a) Accelerated maturation of Cheddar cheese: Microbiology of cheeses supplemented with Lactobacillus casei subsp casei L2A. J Food Sci 57, 345-349

Trépanier G, El Abboudi M, Lee BH, Simard RE (1992b) Accelerated maturation of Cheddar cheese: Influence of added lactobacilli and commercial protease on composition and texture. J Food Sci 57, 898-902

Visser FMW (1977) Contribution of enzymes from rennet, starter bacteria and milk to proteolysis and flavour development in Gouda cheese. 2. Development of bitterness and cheese flavour. Neth Milk Dairy J 31, 188-209 